\title{
Is the Banking Organization Providing IT Enabled Services with Accuracy and Measured Against the Agreed Specifications
}

\author{
N. Viswanadham \\ Department of Accounting and Finance, \\ School of Business Studies, University of Dodoma, Tanzania \\ E-mail: viswa_369@yahoo.com
}

Received: August 26, 2016 Accepted: September 19, $2016 \quad$ Published: January 19, 2017

doi:10.5296/ifb.v4i1.10609 URL: http://dx.doi.org/10.5296/ifb.v4i1.10609

\begin{abstract}
The bank system is facing challenges with stiff competition and advancement of technology. Banks are utilizing the technology based self-service delivery channels to provide anywhere, anytime, anyway banking to customers thereby enhancing and enriching their service experiences. The paper is a research, based on the various issues involved in provisioning of banking services through self-service delivery modes such as ATMs, Internet banking and Mobile banking. Methodology applied included questionnaires, unstructured interview, documentary review and simple random sampling techniques were used to get the respondents. The findings of this study reveal that ATMs are widely used; with internet banking and mobile banking used mostly by certain niche bank customers and both are in the introductory phase with limited patronage. This study recommends that, Bank Management should improve employee's incentives policies regarding customer care from time to time. Also Bank Management should conduct regular research on customers' needs and wants and how to effectively satisfy them.
\end{abstract}

Keywords: Banking, Financial services, Technology banking, IT enabled services 


\section{Introduction}

Banks plays an important role in the economic development of a country. It can provide liquidity. Borrowers and lenders have different liquidity preferences. Banks pool funds together and make them available for the investment. Finding funds through public markets is virtually impossible; banks build relationship with customers that give them valuable information about their operations. Banks administer payment systems which are core to the economy. Before 1919, the currency which was used in Tanzania mainland was the Germany rupee and the subsidiary coins were the Heller Commercial banking which was introduced in 1905, where the Deutsch Ostraafricanische Bank was the first commercial bank. The Bank of Tanzania (BOT) which is the central bank was established in 1966 through the act of 1965. Prior to the BOT establishment, all monetary issues were directed by the East African Currency Board (EACB). The BOT took over the role of EACB and replace the Annual Finance and Credit Plan (AFCP) and the Foreign Exchange Plan (FEP) (Kimei, 1987; BOT, 1995). In an effort to liberalize the banking sector, the Banking and Financial Institution Act, 1991 was introduced to provide the legal framework for banking operations in Tanzania that will grant authorization of financial institutions to receive money on current account subject to withdraw by cheque. As a result of the Act, the entry of new banks has enhanced financial competition resulting into some improvement of the quality and quantity of the financial services offered. Some of commercial banks in Tanzania are NMB bank, CRDB, NBC, Akiba Commercial Bank, Diamond Trust Bank, Standard Chartered Bank, and many more.

\subsection{IT Services in Banks}

In banking in the past, the technology strategy was considered as subordinate to business strategy. But now with so much advancement in technology it has become as important as business strategy. Technology provides an altogether new method of working and interacting with customers rather than replicating human actions (VasantGodse, 2005).

Many of the IT initiatives of banks started in Tanzania in the late 1990s or early 2000 with an emphasis on the adoption of core banking solutions (CBS), automation of branches and centralization of operations in the CBS. Over the last decade, most of the banks completed the transformation to technology-driven organizations. Technology has been implemented successfully in the delivery of many services as an aid to the front-line employee who interacts with the customer (Fisher, 2001).

It's a well-known fact that no business can exist without customers. Not so long ago, accessing our own money was about setting aside a couple of hours, getting to the bank before closing time, standing in one queue to get a token and then in another to collect the cash.

Value according to Zeithaml (1988) is the importance attached to services based on their usage and the amount paid in exchange. Quality on the other hand, is the meeting of the needs and expectations of customers (Parasuraman et al., 1991). Olivia et al. (1992), Fecikova (2004) and ISO (2005) are of the view that satisfaction is the meeting of the needs or wants of customers.

The banking industry is highly competitive, with banks not only competing among each other; 
but also with non-banks and other financial institutions (Kaynak \& Kucukemiroglu, 1992; Hull, 2002). Most bank product developments are easy to duplicate and when banks provide nearly identical services, they can only distinguish themselves on the basis of price and quality. The key factors influencing customers' selection of a bank include the range of services, service charges, fees and prices charged (Brat \& Russell, 1999). So in general, the problems which customers are facing on different services offered by the bank are as follows; Inadequate ICT infrastructure, inadequate funding, absence of appropriate legal and regulatory framework, high cost of bandwidth/telephone lines/internet access, service inter-exchange congestion and slow internet connectivity due to high inter-national tariffs, unexpected system failure, complacence/illiteracy, security (Cyber security, data integrity, protection of customer's confidential information and identity theft).

\section{General Objective}

The general objective of this study is about the study on customer satisfaction on technology based services in commercial banks.

\subsection{Objective of the Study}

To understand whether all the IT enabled services are provided with accuracy and measured against the agreed specification.

\section{Literature Review}

In businesses where the underlying products have become commodity-like, quality of service depends heavily on the quality of its personnel. This is well documented in a study by Leeds (1992), who documented that approximately 40 percent of customer's switched banks because of what they considered to be poor service. Reichheld (1996) suggest that unsatisfied customers may choose not to defect, because they do not expect to receive better service elsewhere. Additionally, unsatisfied customers may look for other providers because they believe they might receive better service elsewhere. However, keeping customers is also dependent on a number of other factors. These include a wider range of product choices, greater convenience, better prices, and enhanced income (Storbacka et al., 1994). Fornell (1992), in his study of Swedish consumers, notes that although customer satisfaction and quality appear to be important for all firms, satisfaction is more important for loyalty in industries such as banks, insurance, mail order, and automobiles.

Ioanna (2002) further proposed that product differentiation is impossible in a competitive environment like the banking industry. Banks everywhere are delivering the same products. In Latin America and Africa, e-banking has however been less successful, according InfoDev. Developing a successful e-banking for poor people entails managing a host of inter-related issues - technology, pricing, financial literacy, functionality, partnerships, delivery channels, POS distribution and regulation (Elinaza, 2011).

According to Adam et al. (2008) as we witness the globalization of markets, a major instrument of it is the development in communications and information technology. This development has therefore made the introduction of electronic purse a reality in banking and is redefining what a 
legal lender is in monetary terms (Abratt et al., 1999).

The Visa International Network, the largest e-payment service provider is a membership association owned by more than 21000 financial institutions around the world that provides member institutions with global payment platform development.

Storbacka et al. (1999) pointed out that, in South Africa, smart cards are being put to use in various areas: salaries, pensions, car parks, post offices, cinemas and stadia. Because of the pervasive use of the smart card in that country, security measures which are linked to biometric verification, usually the electronic reading of finger print fraud is usually non- existent (Ovia, 2003).

Cabas (2001) noted investment opportunities, reduction in costs, satisfaction of customers and competitiveness as motives to install and add new ATM to the existing network. Moutinho (1992) established that ATM facility resulted in speed of transactions and saved time for customers.

Researchers have divergent views about the use and effectiveness of ATMs. Stemper (1990) stressed the positive dimension of ATMs based on freedom of transaction. Effective service delivery in ATM system guarantees quality excellence and superior performance and provide autonomy to the customers (Lovelock, 2000). Yavas et al. (2004) argued that customers' focused ATM delivery system that fulfills their needs and maximize operational performance are essential dimensions for bank to achieve and sustain competitive advantage. Dilijonas et al. (2009) examined the essential aspects of ATM service quality in Baltic States. A customer may not be able to use telephone banking on particular bank accounts with a financial institution, such as loan accounts, but bank rules vary in this respect (Mubarak, 2007).

A study by Stake (1998) suggests that satisfaction has a stronger impact on loyalty online than offline, possibly due to high search costs for alternative providers. Satisfaction has been defined as a cumulative, attitude-like judgment that is based on customers' past experience. It is connected to varying emotional and cognitive states that influence customers' future behavior towards the company (Slater, 1997).

According to Elinaza (2011) financial institutions on a global scale have lost over $\$ 5$ billion to internet banking fraud from 2005 to 2007. He further stressed that, when such losses are incurred, banks are very fast in passing the bill to the final consumer (bank customers) which doesn't create any value to them. This situation heightens fear amongst consumers of this very product/service.

Oliva (1992) contended that as the internet grows towards becoming a standard for information access, retrieval and exchange, a need has arisen to take "a safe” level of participation in the emerging product/service in the banking industry.

Kaynak \& Kucukemiroglu's (1992) study of the Hong Kong banking market discovered that customers choose their banks because of convenience, long association, recommendations of friends and relatives, and accessibility to credit.

Reidenbach (1995) argued that customer value is a more viable element than customer 
satisfaction because it includes not only the usual benefits that most banks focus on but also a consideration of the price that the customer pays. Customer value is a dynamic that must be managed. Bharadwaj (1993) argued that services are highly intangible and are, therefore, high in experience and credence qualities. As a consequence, brand reputation is important as a potential competitive advantage. Alvarez (2001) proposed that logic is no longer enough to sell the benefits of an intangible product or service, especially with commodity products and skeptical consumers. Curasi \& Kennedy (2002) have shown that customer satisfaction does not predict the continuation of the relationship. High switching costs are an important factor binding the customer to the service organization. Sathye (1999), in his research paper, explored the factors affecting the adoption of internet banking by Australian customers. The author stated that internet and other virtual banking had significantly lower the cost structure than traditional delivery channels. So, the banks should encourage customers to use internet for banking transactions. Mattila et al. (2003) evaluated the electronic banking adoption in Finland. The study showed that the proportion of people in Finland, who have adopted online banking, was higher than anywhere else in the world. All the Finnish banks offered a full range of internet banking services. The researchers also found that different people have different attitude towards new technology. Some were innovators, who were interested in new technology and positive towards it. Some were early adopters and some were late adopters who have negative attitude towards it. In a highly competitive market, the shortest route to differentiation is through the development of brands and active promotion to both intermediaries and final consumers (Parasuraman, 1997). In the long run, however, branding, targeting and positioning would all be much more effective if the supplier had some tangible advantage to offer consumers (Baker, 1993).

\section{Research Methodology}

\subsection{Study Area}

According to Develeux \& Hoddlinot (1992), a researcher needs to select a specific area for the study, since only specific locations, and not areas, are ideal and suitable to test a particular theory. The study was conducted at Dodoma Municipal in Dodoma Tanzania in 2014/2015. The area has some of the commercial banks which are found in.

\subsection{Research Technique}

The researcher analyzed the data collected by using qualitative and quantitative methods. The data collected have been compared in both qualitative and quantitative techniques. Then the qualitative technique was adopted to elaborate the quantitative used.

Kombo (2004) argued that, the greater the diversity and differences that exist in the population, the larger the researcher's sample size should be. Capturing the variability in the population allows for more reliability of the study. Therefore, population of study was supposed to be 100 people but only 94 respondents returned their filled in questionnaires. The size was selected in order to fulfil the requirements of efficiency, representativeness, reliability and flexibility (Kothari, 2005). The targeted population was all those customers using IT enabled services from different commercial banks in Dodoma Municipality 


\subsection{Data Collection Methods and Instruments}

Different methods employed to increase the reliability of the collected data. Fontana and Frey (2005) argued that, the use of different methods known as "triangulation" minimizes the possibility of making erroneous conclusion and increases the credibility of the findings. The study involved use of different tools to secure their accuracy and to validate collected data.

\subsection{Data Analysis Technique}

In this study, the data was analyzed basing on both qualitative and quantitative techniques, where by the analysis was conducted through the use of tables and percentages which was calculated and through the use of conceptualization.

\section{Analysis}

Table 1. Distribution of respondents by sex

\begin{tabular}{|l|l|l|}
\hline Item & Frequency & Percentage \\
\hline Male & 53 & 56.38 \\
\hline Female & 41 & 43.62 \\
\hline Total & 94 & 100 \\
\hline
\end{tabular}

Source: Field data, 2015.

Responses of males were more (56.38\%) as compared to female who were $43.62 \%$, this might be in cycle with the global trend which shows that more males utilize these IT enabled services in banks compared to females.

Table 2. Distribution of respondents by age

\begin{tabular}{|l|l|l|}
\hline Item (in years) & Frequency & Percentage (\%) \\
\hline Under 25 & 44 & 46.81 \\
\hline $26-35$ & 40 & 42.55 \\
\hline $36-45$ & 3 & 3.19 \\
\hline Above 46 & 7 & 7.45 \\
\hline Total & 94 & 100 \\
\hline
\end{tabular}

Source: Field data, 2015.

During data collection period age of the respondents was put into consideration in order to get information from different age groups. The age of respondents were grouped in the age groups with the range of 10 years of age which is under 25 years, the age between 26-35 years, 36-45 years and the age above 46 years. From the table above it is found that $46.81 \%$ of the respondents are below 25 years which is the highest number compared to other age groups. 
Table 3. Distribution of respondents by occupation

\begin{tabular}{|l|l|l|}
\hline Item & Frequency & Percentage (\%) \\
\hline Employed by government & 15 & 15.96 \\
\hline Employed by private sector & 29 & 30.85 \\
\hline Self employed & 17 & 18.09 \\
\hline Students & 33 & 35.11 \\
\hline Total & 94 & 100 \\
\hline
\end{tabular}

Source: Field data, 2015.

About 35.11 percent of the responses are the students studying in colleges. The other group which uses more of the services are those employed by private institutions which is 30.85 percent compared to self-employed which is 18.09 percent this may be so as many of them use the money for buying commodities for selling, so the money is always in circulation.

Table 4. Users of various channels

\begin{tabular}{|l|l|l|}
\hline Item & Frequency & Percentage (\%) \\
\hline ATM users & 92 & 98 \\
\hline Internet banking users & 18 & 19 \\
\hline Mobile banking users & 26 & 27 \\
\hline Total responses & 94 & 100 \\
\hline
\end{tabular}

Source. Field data, 2015.

From table above, 92 respondents use an ATM service which is $98 \%$ of all the respondents, which means almost all use ATM service with or without other IT services. But only 18 which is $19 \%$ of all respondents are using Internet Banking and are minimum in number, for the Mobile banking services 26 which is $27 \%$ of the total respondents are using this channel mode.

Table 5. Channel combination users

\begin{tabular}{|l|l|l|}
\hline Item & Frequency & Percentage (\%) \\
\hline ATM only & 82 & 87 \\
\hline ATM\& Internet Banking & 18 & 19 \\
\hline ATM\& Mobile Banking & 28 & 30 \\
\hline ATM, Internet Banking \&Mobile Banking & 10 & 11 \\
\hline
\end{tabular}

Source: Field data, 2015.

Table shows that, out of the respondents' majority of them use only ATM (87\%) followed by 
the respondents who use ATM and Mobile Banking, which is 30\%. Respondents who use ATM and Mobile banking services took 19\% of all the respondents. Only few (11\%) respondents use all the three channels.

Table 6. Satisfaction level

\begin{tabular}{|l|l|l|l|}
\hline Satisfaction Level & ATM Users (\%) & Internet Banking (\%) & Mobile Banking \\
\hline Highly satisfied & 36.1 & 25.8 & 22.6 \\
\hline Satisfied & 52.8 & 49.1 & 47.4 \\
\hline Neither & 3.7 & 15.7 & 15.3 \\
\hline Dissatisfied & 1.4 & 10.9 & 12.4 \\
\hline Highly dissatisfied & 0.0 & 2.5 & 2.3 \\
\hline Total & 100 & 100 & 100 \\
\hline
\end{tabular}

Source: Field data, 2015.

The satisfaction level of the automated banking delivery channels as indicated in table above shows in general that it is high as it has $88.9 \%$ of the ATM users are satisfied or highly satisfied, about $3.7 \%$ responded that they are neither satisfied and $1.4 \%$ they are dissatisfied. None of the respondents said they are totally dissatisfied with the ATM usage. About $74.9 \%$ of the internet banking users are satisfied or highly satisfied with15.7\% responded that they are neither dissatisfied nor satisfied and $10.9 \%$ said they are dissatisfied with $2.5 \%$. In case of Mobile banking users, $70 \%$ are satisfied or highly satisfied with $15.3 \%$ responding that they are neither satisfied nor dissatisfied, $12.4 \%$ said they are dissatisfied and only $2.3 \%$ showed that they are highly dissatisfied.

Table 7. Overall IT service quality

\begin{tabular}{|l|l|l|l|}
\hline Item & ATM & Internet Banking & Mobile Banking \\
\hline Excellent & 10 & 5 & 8 \\
\hline Very good & 37 & 12 & 10 \\
\hline Good & 35 & 10 & 12 \\
\hline Average & 5 & 0 & 4 \\
\hline Poor & 0 & 0 & 0 \\
\hline
\end{tabular}

Source: Field data, 2015.

From the table above, it shows that for the ATM users 37 respondents agreed the service is very good, 35 respondents agreed it is good, 10 respondents said the service is excellent, only 5 responded the service is average and no one said that the ATM service quality is poor.

For the case of Internet banking 12 users responded that the service is very good, 10 showed 
that it is good, 5 showed that the service is excellent and none responded the service is average or poor.

Mobile banking users, 10 responded that mobile banking service is very good, 12 responded the service is good, 8 agreed the service is excellent and 4 showed the service is average. None responded the mobile banking service to be poor.

Table 8. IT facility given more importance in the bank

\begin{tabular}{|l|l|l|}
\hline Item & Frequency & Percentage \\
\hline ATM & 90 & 95.7 \\
\hline Internet banking & 3 & 1.1 \\
\hline Mobile banking & 1 & 3.2 \\
\hline Total & 94 & 100 \\
\hline
\end{tabular}

Source: field data 2015.

Among the three modes of IT delivery channels, the one which is given more importance in banks is the ATM service which is 95.7 percent as shown in the table. Internet banking and mobile banking is given less importance as they have less percentage.

\section{Discussion}

Generally, many commercial banks have tried their level best to make these three modes of IT self-service delivery channels to be known to the citizens and be used by the bank customers. Banks aim was to ensure high usage of those IT enabled services so that they can move from a manual, scale constrained environment to a global presence with the automated systems and processes (BOT, 2010). However, it encountered with a number of problems such as that of not many bank customers are using these technologies based service delivery channels especially the aged ones.

ATM has the widest adoption and acceptance, so this channel could primarily be the channel of all the automated delivery channels that could be promoted by the banks. From the usage pattern it is found that ATM right now is only used as a cash dispensing machine, so the banks can encourage the usage of more functions of ATMs, and introduces ATM with additional capabilities.

Another channel is Internet banking as this has a limited patronage and a major reason for its non-use is that customers are happy with other modes of transaction, it means they are not comfortable with it. Another reason is the security concerns, so the banks have to take measures to train the customers and assure them that using this mode of service is both convenient and safe. Lack of awareness could also be another reason for its non-adoption. This mode is also found to be versatile since customers can be comfortable accessing the banking services from their homes; also it has good future and potential amongst certain segments of bank customers. 
Even though mobile banking users are satisfied and have positive perceptions about the services, it also has a limited patronage. This is because there is a problem of non-awareness among respondents which prevent the usage of this service. Another reason could be the wide availability of other modes of transactions such as ATMs and internet banking.

It has been found that many bank customers do not use these IT enabled services because they do not know how to use them. Also it is found from the findings that the highly educated and young, relatively well of segment of the customers are the ones who mainly use the technology based service delivery channels.

The researcher observed that in case of ATMs, there are few ATM booths which many of them are situated in town, so someone has to go to town where the bank's buildings are situated for the service.

In case of Mobile banking services the service can delay due to some problems in internets. For example a customer may want to buy electricity (lulu) through mobile banking but the message for the units may not come on time due to internet problems.

It is found from the research that many bank customers do not trust this Internet banking services due to insecurity/lack of confidence. Information is transferred via Internet. Internet banking is, therefore, inherently risky from the viewpoint of insecurity. Moreover, Internet banking is willing to depend on, or intends to depend on, the cultivation of trust.

\section{Conclusion}

Accordingly, the results of this research paper confirmed the theory of literatures regarding the customer satisfaction and the use of IT enabled services in banking industry. Securities, lack of facility, improper awareness and so on were found to be the reasons for not using IT enabled services. The customers' assessment of a particular automated delivery channel and their intention to use a particular delivery channel depends on their perceptions about the various attributes of that particular delivery channel. That is, every different channel has its own attributes, which differ from the others, so it is important to measure the quality of each channel separately and this greatly influences the customer choice of that channel.

\section{References}

Abratt, R., \& Russell, J. (1999). Relationship Marketing in Private Banking South Africa. The International Journal of Bank Marketing, $17(1), \quad 5$. https://doi.org/10.1108/02652329910254000

Adam, J., \& Kamuzora, F. (2008). Research Method for Business and Social studies. Mzumbe University, Morogoro.

Alvarez, E. J. (2001). Your Bank’s Image: Keeping it Consistent. Bank Marketing, 33(3), 30-36.

Bharadwaj, S. G., Varadarajan, P. R., \& Fahy, J. (1993). Sustainable Competitive Advantage in Service Industries: A Conceptual Model and Research Propositions. Journal of Marketing, 57(October), 83-99. https://doi.org/10.2307/1252221 


\section{Macrothink}

Cabas, M. G. (2001). A History of the Future of Banking: Predictions and Outcomes. [Online] Available: http://www.hass.berkeley.edu/finance/CMWpaper.pdf

Curasi, C. F., \& Kennedy, K. N. (2002). From Prisoners to Apostles: A Typology of Repeat Buyers and Loyal Customers in Service Businesses. The Journal of Service Marketing, 16(4), 322-342. https://doi.org/10.1108/08876040210433220

Develeux, J. S., \& Hoddlinot, J. (1992). Field work in developing countries. Harvester Wheat Sheaf, Tokyo, Japan.

Dilijonas, D., Krikšciunien, D., Sakalauskas, V., \& Simutis, R. (2009). Sustainability Based Service Quality Approach for Automated Teller Machine Network. Accessed, pp. 241-246.

Elinaza, A. (2011). E-banking in Tanzania, Daily News Magazine of 22nd June.

Fecikova, I. (2004). An Index Method of Measurement of Consumer Satisfaction. TMQ Magazine, 16(1), 57-66. https://doi.org/10.1108/09544780410511498

Fisher, A. (2001). Winning the Battle for Customers. Journal of Financial Services Marketing, 6(1), 77-84. https://doi.org/10.1057/palgrave.fsm.4770042

Fornell, C. (1992). A National Customer Satisfaction Barometer: The Swedish Experience. Journal of Marketing, 56, 6-21. https://doi.org/10.2307/1252129

Hull, L. (2002). Foreign-owned Banks: Implications for New Zealand's Financial Stability. Discussion Paper Series, DP2002/05. https://doi.org/10.2139/ssrn.318020

Ioanna, P. D. (2002). The Role of Employee Development in Customer Relations: The Case of $\begin{array}{llll}\text { UK Retail Bank. Corporate } \quad \text { Communication, } & \text { 7(1), }\end{array}$ https://doi.org/10.1108/13563280210416053

Kaynak, E., \& Kucukemiroglu, O. (1992). Bank and Product Selection: Hong Kong. The International Journal of Bank Marketing, 10(1), 3-17. https://doi.org/10.1108/02652329210007858

Kombo, D. (2004). Proposal and Thesis Writing (2nd ed.). Nairobi Kenya: Paulines' Publications Africa.

Kothari, C. (2005). Research Methodology; Methods and Techniques (2nd ed.). New Delhi: New Age International (P) Ltd Publishers.

Leeds, B. (1992). “Mystery Shopping” Offers Clues to Quality Service. Bank Marketing, 24(11), 24-27.

Lovelock, C. H. (2000). Functional integration in service: understanding the links between marketing, operations, and human resources.

Mobarek, A. (2007). E-Banking Practices and Customer Satisfaction-a Case Study in Botswana. https://doi.org/10.2139/ssrn.1011112

Moutinho, L. (1992). Customer Satisfaction Measurements: Prolonged Satisfaction with 
ATMs. International Journal of Bank Marketing, 10(7), 30-37. https://doi.org/10.1108/02652329210021131

Moutinho, L., \& Brownlie, D. T. (1989). Customer Satisfaction with Bank Services: a Multidimensional Space Analysis. International Journal of Bank Marketing, 7(5), 23-27. https://doi.org/10.1108/02652328910131926

Oliva, T. A., Oliver, R. L., \& Macmillan, I. C. (1992). A Catastrophe Model and Developing Service Satisfaction Strategies. Journal of Marketing, 56(3), 83-96. https://doi.org/10.2307/1252298

Parasuraman, A. (1997). Refection on gaining competitive advantage through customer Value. Journal of the academy of marketing Science, 25(2), 154-161. https://doi.org/10.1007/BF02894351

Reichheld, F. F. (1996). Learning from Customer Defections. Harvard Business Review, March/April, pp. 56-69.

Reidenbach, R. E. (1995). Value-Driven Bank: Strategies for Total Market Satisfaction. Irwin Professional, U.K.

Slater, S. F. (1997). Developing a Customer Value-Based Theory of the Firm. Journal of the Academy of Marketing Science, 25(Spring), 162-167. https://doi.org/10.1007/BF02894352

Stake, R. E. (1998). Case Studies. In N. K. Denzin \& Y. S. Lincoln (Eds.), Strategies of Qualitative Inquiry. Thousand Oaks, London, New Delhi: Sage Publications, International Educational and Professional Publisher.

Stemper, R. G. (1990). The Guide to Successful Consumer Banking Strategy. Chichester and Toronto: John Wiley \& Sons.

Storbacka, K., Strandvik, R., \& Gronroos, C. (1994). Managing Customer Relationship for Profit: The Dynamics of Relationship Quality. International Journal of Service Industry Management, 5(5), 21-38. https://doi.org/10.1108/09564239410074358

Zeithmal, V. A. (1988). Consumer Perceptions of Price, Quality and Value: A Means- End Model and synthesis of evidence. Journal of Marketing, 52(3), 2-22. https://doi.org/10.2307/1251446

\section{Copyright Disclaimer}

Copyright for this article is retained by the author(s), with first publication rights granted to the journal. This is an open-access article distributed under the terms and conditions of the Creative Commons Attribution license (http://creativecommons.org/licenses/by/3.0/). 